\title{
The Impact of External Debt and Foreign Direct Investment on Economic Growth: Empirical Evidence from Tanzania
}

\author{
Moga Tano Jilenga ${ }^{1}$, Helian $\mathrm{Xu}^{1} \&$ Igor-Mathieu Gondje-Dacka ${ }^{2}$ \\ ${ }^{1}$ College of Economics and Trade, Hunan University, Changsha, China \\ ${ }^{2}$ School of Finance and Statistics, Hunan University, Changsha, China \\ Correspondence: Moga Tano Jilenga, College of Economics and Trade, Hunan University, Changsha 410079, China.
}

Received: February 25, 2016

Accepted: March 16, 2016

Online Published: March 21, 2016

doi:10.5430/ijfr.v7n2p154

URL: http://dx.doi.org/10.5430/ijfr.v7n2p154

\begin{abstract}
This study investigates the impact of external debt and Foreign direct investment (FDI) on economic growth in Tanzania using time series data from 1971-2011. The empirical analysis was based on ARDL model and the Bounds test approach of co-integration as advocated by Pesaran et al (2001) to test for long-run equilibrium relationship. The results show that, in the long-run debt promote economic growth in Tanzania. However, foreign direct investment exhibits a negative impact on economic growth. While in the short-run, the results indicate that there is no directional causality either between external debts (PD) and economic growth (RGDP) or between FDI_INFL and economic growth (RGDP).
\end{abstract}

Keywords: external debt, FDI, economic growth, ARDL, co-integration, Tanzania

\section{Introduction}

In order to achieve long - lasting sustainable economic growth, developing countries need to make strategic decisions in order to attain the desired level of growth. Financing decisions is the area which policy decision makers need to put more emphasis. The sources of financing a deficit budget by a country may include but not limited to external borrowing, foreign direct investment and official development assistance from developed countries which has continuously being curtailed. In this part we provide a brief overview of FDI and external debt in Tanzania as indicated below.

\section{Foreign Direct Investment in Tanzania}

Foreign Direct Investment (FDI) has been subject to debates in the past two decades in both developing and developed countries. FDI has been considered as an important source of financing investments especially in emerging and developing economies. As global economies are growing and becoming more and more open due to relaxation of regulations on international trade; integration among countries has also increased resulting to global capital movement flows which are normally facilitated by the operations of Multinational enterprises (MNEs).

The world investment report (WIR) published in 2012 indicate that there has been an increase in foreign investment flow in Tanzania. The report shows that during the past one year, Tanzania became the top in attracting FDI in the East African region by attracting 1.1 billion USD equivalents to (TZS 1.76 trillion). However, the report also highlighted that between June, 2012 Tanzania overtook Kenya the region's biggest economy; indicating the high confidence among foreigner investors to Tanzania as a result of favourable environment in the country due to peace as well as many investment opportunities available. The same report pointed out that for the past three years, Tanzania has attracted about 47 percent of all FDI flows in the five East African countries. In addition, the report issued by UNCTAD in 2014, indicate that Tanzania recorded the highest FDI in 2013 within East African Community.

This increase in FDI can be attributable to the Government efforts to improve the existing investment climate by reviewing the existing policies and instituting new ones geared to provide incentives to both foreign and domestic investors and make easy for investors to conduct business in the country. It is argued that FDI inflows contribute towards increased employment, increase revenue in terms of taxes collected, technology spillover and innovation to the host country. 
The investment potentials available in Tanzania including agriculture and agribusiness, infrastructure development, manufacturing, tourism, financial services, mining, water resource development a few to mention. These areas have attracted many investments in the country. Again, following recently discovery of large deposits of gas in the country, the Government expects to attract more FDI in gas sector. The Tanzania parliament has recently passed gas laws to provide legal framework to be used in gas industry in order to protect and control this important resource for development.

Despite the increase in foreign direct investment in Tanzania as evidenced by UNCTAD reports; there are still questions to be asked on whether the increase in FDI has a significant impact on economic growth. This is why there is a need to investigate the impact of FDI on economic growth in Tanzania.

\section{Tanzania External Debt overview}

Many countries in the world do borrow in order to finance various sectors of their economies especially industry, energy, transport and communication, education and agriculture among others which results in external debts. Tanzania in this regard is not on exception; for some good reasons the Government has borrowed and has been borrowing funds to finance some projects due to budget deficit or having low investment in the country on condition to repay the loan within a specific period of time.

The Bank of Tanzania (BOT) recently revealed that the national debt stock hit 40 trillion TZS in July 2015 which is about four times what it was 10 years ago. The new indebtedness was an increase of 29.4 trillion of what the public debt was in July 2005. The debt increased by 24.2 trillion between December 2010 and July 2015. This is economically detrimental and puts Tanzania in awkward fiscal posture and the country's creditworthiness locally and internationally becomes doubtful creating fear of debt crisis especially if the money borrowed were not well invested in projects that generate returns for loan repayment.

According to Ndullu, (1994) a significant proportion of development investments (including textile and other factories, transport and power infrastructure) were financed through external debt, and its low productivity greatly resulted in debt servicing problems. Debt servicing is identified as a serious threat to economic growth of any country especially for low income countries like Tanzania.

Perkins D. H. et al (2001) argued that foreign borrowing for a country is necessary especially if the borrowed funds are used to finance economic development. However, too much foreign borrowing and borrowing to finance consumption or poor investment can lead to big trouble. A country's debt portfolio has to be prudently managed to ensure that they reap the gain while avoiding the possibility of crisis. The magnitude of the external debt of developing countries has caused their policy- makers to feel that this poses severe financial obstacles to national development. Debt - service payments have to be made at the expense of foregoing a number of projects and efforts to meet human needs.

Although many empirical studies confirm that FDI have positive impact on economic growth, yet the size of such impact may vary across countries depending on the level of institutional framework necessary to foster investment as well as specific policies to enable the host economy reap the benefit from FDI. This ambiguity inhibits our understanding required to promote economic growth and set clear investment policies particularly for the case of Tanzania. In addition, the question arises whether external debt has an impact on economic growth in Tanzania.

The objective of this study is to investigate the impact of external debt and FDI on economic growth of Tanzania. The results from this paper are expected to contribute to knowledge on existing literature about the impact of external debt and FDI on economic growth. In addition, the study is of significance to investors and policy makers in realizing policy issues on external debt and FDI. The paper is organized in five sections, next to this section is, section two which provides a brief summary of empirical literature, section three provides methodology and model specification, while section four shows empirical results and analysis and finally section five provides summary and conclusion of the study.

\section{Literature Review}

\subsection{Empirical Review on FDI and Economic Growth}

Many studies have been conducted to investigate FDI and its impact on economic growth in both developed and developing countries. Most of studies find a positive contribution of FDI to the host country's economic growth. However, some previous studies undertaken on the impact of FDI on economic growth indicate a negative impact on economic growth. Additionally, some of empirical studies have mixed conclusions as regards to the impact of FDI and economic growth. The main reason for the different findings may be due to different methods used and specific macroeconomic variables considered for a particular country. In order to shed some light on the understanding of this area, below are the previous studies conducted in different countries. 
Islam (2014) examined the impact of FDI on Bangladesh economy using secondary data for the years from 1996 2010. He argues that FDI in Bangladesh plays an important role in achieving expected economic growth. The results show that FDI has a positive correlation with GDP, export and private investment. Similarly, SidratulMuntah et al (2015) investigated the impact of Foreign Direct Investment on economic growth of Pakistan. Their findings indicate that FDI is positively related with GDP. Their conclusion is that Pakistan should adopt the FDI projects to promote economic growth. Again, Ayanwale (2007) examined FDI and economic growth in Nigeria. The findings for the study show that FDI induces nation's economic growth. Although the overall effect of FDI on the whole economy may not be significant.

Additionally, Melnyk et. al (2014) investigated the impact of forign investment on the growth of 26 post communism transition economies from 1998 to 2010 and suggested that FDI has influence on growth of these economies. Al Khathlan, (2014) used co- integration technique to investigate the long-term relationship between FDI inflows and economic growth from 1980 to 2010 in Saudi Arabia. He found a positive significant relationship with economic growth.

On the contrary, a study on the impact of foreign direct investment on economic growth of Pakistan by Saqib et. al (2013) reveal that Pakistan's economic performance is negatively affected by foreign investment while its domestic investment has benefited its economy. It can therefore be argued that domestic investment would benefit the country's economy, and the dependency on foreign investment should remain limited. In this regard, it seems that most of the benefits of foreign investment get diluted at the hands of the repatriation of profits back to the investor nation. This can also be explained by the limited capacity of the host country to diffuse the transfer of knowledge and technology for further development.

In a different perspective, Alfayo (2003), using cross -country data suggest that total FDI exerts an ambiguous effect on growth. He further argued that foreign direct investment in the primary sector tends to have a negative effect on growth, while investment in manufacturing a positive effect. Evidence from the service sector is ambiguous.

\subsection{Empirical Reviewon External Debt and Growth}

Wamboye (2012) evaluated the impact of public external debt on long term economic growth of fourty least developed countries (LDC's) using unbalanced panel data from 1975 - 2010. The findings on this study suggest that high external debt depresses economic growth, regardless of the nature of the debt. In addition, debt relief initiatives are crucial as evidenced in the lower negative debt effects on growth in HIPCs sub - sample relative to non - HIPCs. Michael and Sulaiman (2012) examined the impact of external debt on the level of economic growth and the volume of investment in Nigeria for the period 1980 - 2008. The results of their analysis indicate that there exists a positive relationship between external debt, economic growth and investment. Their findings indicate that external debt ratio of GDP stimulates growth in the short - term; the private investment which is a measure of real and tangible development shows a decline.

According to Benedict et.al, (2003) a large external debt can also affect growth through the crowding out effect or by affecting the composition of private investment. An increasing debt service may increase the government's interest bill and the budget deficit and consequently, cause the long-term interest to rise or simply crowd out credit available for private investment (Gale and Orzag, 2003; Baldacci and Kumar, 2010). Similarly, heavy debt burdens acts to reduce investment through both debt overhang and the crowding out effect (Iyoha, 1997). Chauvin and Kraay (2005) show that debt relief in 62 developing countries between the years $(1989-2003)$ did not improve the institutional quality nor lead to rising FDI or higher rates of economic growth.

In summary the previous literature on the impact of FDI on economic growth are inconclusive. While some studies show a positive relationship other studies indicate a negative influence on economic growth. However, the overall effect of FDI on the whole economy provides ambiguous results. This ambiguity necessitates a further investigation particularly for Tanzania where the trend of FDI flows is on increase. On the other hand, external debt as another source of finance has been increasing on yearly basis due to deficit budget especially for development projects. The burden to the nation is extremely high as the external debt tends to attract interest. Our study therefore investigates the impact of FDI and external debt on economic growth.

\section{Methodology and Model Specification}

\subsection{Data and Methodology}

The data were collected from the INDEX MUNDI which provides data from IMF and World Development Indicators (WDI) websites. The data are fully secondary and covers the period of years 1971-2011. However, we apply econometrics methods to assess the impact of FDI and external debt on economic growth. 


\subsection{Model Specification}

The model is developed based on six (6) variables, RGDP, PD, FDI INFL, EXRATE, PRED and NODA. It is assumed that RGDP (Real Gross Domestic product) is a function of PD (external Debt), FDI_INFL (FDI Inflow), EXRATE (Exchange Rate), PRED (Principal repayments on external debt) and NODA (Net official development assistance). In other words these RGDP is a dependent variable and the remaining five variables are explanatory variables.

Our assumption is that FDI and External debt affect economic growth:

The model now can be specified as follows:

$$
R G D P_{t}=f\left(P D_{t}, F D I_{-} I N F L_{t}, E X R A T E_{t}, P R E D_{t}, N O D A_{t}\right)
$$

Where, script' $t$ ' denotes time period.

To estimate properly the parameters and facilitate the interpretation, the variables are transformed and the final model becomes;

$$
\Delta R G D P=\alpha+\beta_{1} \Delta \ln P D+\beta_{2} \Delta F D I \_I N F L+\beta_{3} \Delta E X R A T E+\beta_{4} \Delta \ln P R E D+\beta_{5} \Delta \ln N O D A+\varepsilon
$$

Where,

RGDP is the real GDP is the dependent variable and indicates economic performance of a country. It indicates the value of goods and services produced in particular period normally a year adjusted for inflation.

$\ln P D$ is the natural log of Public Debt and refers to the total external debt of a country. It can be used as a determinant of macroeconomic growth. According to International Monetary Fund (IMF) 'Gross external debt' is the amount at any given time, of disbursed and outstanding contractual liabilities of residents of a country to non residents to repay principal, with or without interest, or to pay interest, with or without principal. It is argued that a highly indebted economy is perceived to be in trouble.

\section{FDI_INFL}

Foreign direct investment inflow (FDI_INFL) according to Wikipedia it refers to a controlling ownership in a business enterprise in one country. It includes the value of inward direct investment made by nonresident investors in the reporting economy, including reinvested earnings and intra company loans. FDI provide external capital and advanced technology to the economy which acts as the engine for economic growth.

LnNODA (natural log of net official development assistance)

Consist of disbursement of loans on concessional terms (net of repayment of principal) and grants by official agencies of the members of the Development Assistance Committee to promote economic development and welfare in developing countries. It acts as a key for Millennium Development Goals (MDGs) achievement.

EXRATE (natural log of real exchange rate)

It is inflation - adjusted measure that reflects the value of goods and services produced in a given year. It gives a measure of competitiveness, and is useful variable for explaining trade behavior and national income.

InPRED (natural log of principal repayment on external debt)

Are the payments of economic value for external debt by a country by the debtor to the creditor that reduce the principal amount of external debt outstanding.

$\varepsilon$ represents an error term.

According to Hendry and Juselius (2000), time series data can represent unit root behavior. Such data cannot be used to investigate relationships between the variables because of spurious regression problem, so using OLS for estimating time series data become invalid. However, data showing such properties can be made stationary by first differencing or second differencing. According to Granger and Swanson (1996), if a series is such that its first difference is stationary (and has positive spectrum at zero frequency) then the series has an exact (or pure) unit root. 


\section{Empirical Results and Analysis}

\subsection{Unit Root Testing}

Dickey and Fuller (1979) had developed the test to determine whether a variable has a unit root. The null hypothesis for this test is that the variable that is in use for analysis contains a unit root.

For the unit root test, the AR(1) model as the equation 1 is reproduced adding a constant term $\alpha$, time trend and a coefficient that are so significant in the development for the test statistic.

$$
\Delta y_{t}=\alpha+\rho y_{t-1}+\delta t+\varepsilon_{t}
$$

An extension of equation 3 is done to remove possibilities of serial correlation in the lagged variables by taking $p$ lagged differences and fitting a model as shown in Equation 4 below;

$$
\Delta y_{t}=\alpha+\beta y_{t-1}+\delta t+\varphi_{1} \Delta y_{t-1}+\varphi_{2} \Delta y_{t-2}+\varphi_{3} \Delta y_{t-3}+\ldots .+\varphi_{k} \Delta y_{t-k}+\mu_{t}
$$

For the Dickey-Fuller test, if the test statistics is smaller (larger) than the critical values we do not reject (reject) the null hypothesis for the unit root in the data.

The unit root test statistics starts from the Augmented Dickey-Fuller expression (equation 5) below:

$$
\Delta y_{t}=\alpha+\beta y_{t-1}+\delta t+\varphi_{1} \Delta y_{t-1}+\varphi_{2} \Delta y_{t-2} \ldots \ldots+\varphi_{k} \Delta y_{t-k} \in_{t}
$$

Where $k$ is the number of lags specified in the lags ( ) option. The non-constant option removes the constant term $\alpha$ from this regression, and the trend option includes the time trend $\partial t$, which by default is not included. Testing $\beta=0$ is equivalent to testing $\rho=1$, or, equivalently, that $y_{t}$ follows a unit root process (Stata Press Publication, 2013). The test provides that the null hypothesis is that the variable contains a unit root if the P-value of the coefficient is higher than $5 \%$.

There are many unit root tests used to test whether the variables are stationary when using time series data. For this study we opted to use three different tests; Augmented Dickey-Fuller (ADF), Phillips-Perron (PP) test and Kwiatkowski- Phillips-Schmidt- Shin (KPSS) test. In hypothesis testing, we assume that if (P-value $<0.05$ ), we reject the null hypothesis and conclude that the variable is stationary otherwise we accept it. We can say also that if the absolute value of the test statistic is greater than the $5 \%$ critical value, we can reject the null hypothesis that the variable have unit root otherwise we fail to reject the null hypothesis.

The unit root test is done in three forms. The first test is by using intercept, the second test is by using trend and intercept and the final test is by using neither trend nor intercept.

Table 1. Unit root test results

\begin{tabular}{cccc}
\hline Series & ADF test & PP test & KPSS test \\
\hline RGDP & $-2.997^{* *}$ & $-10.187^{* *}$ & $0.472^{* * *}$ \\
& $(-2.937)$ & $(-2.937)$ & $(0.347)$ \\
LNPD & $-3.774^{* * *}$ & $-3.774^{* * *}$ & $0.187^{* * *}$ \\
& $(-2.607)$ & $(-2.607)$ & $(0.119)$ \\
FDI_INFL & $-12.465^{*}$ & $-12.205^{*}$ & $0.614^{* *}$ \\
& $(-3.610)$ & $(-2.610)$ & $(0.463)$ \\
EXRATE & $-4.474^{* * *}$ & $-4.372^{* * *}$ & $0.735^{* * *}$ \\
& $(-3.196)$ & $(-3.196)$ & $(0.347)$ \\
LNPRED & $-5.731^{* *}$ & $-5.707^{* *}$ & $0.412^{* * *}$ \\
& $(-2.939)$ & $(-2.939)$ & $(0.146)$ \\
LNNODA & $-5.446^{*}$ & $-5.502 * *$ & $0.723^{* * *}$ \\
& $(-3.610)$ & $(-3.610)$ & $(0.347)$ \\
\hline
\end{tabular}

Note: The values in brackets are the t-statistics of corresponding estimated coefficients, and ${ }^{* * *},{ }^{* *}$ and ${ }^{*}$ denote significance at $1 \%, 5 \%$ and $10 \%$, respectively. 
Using ADF test we found that all variables have no unit root at I(1) except RGDP and lnPD which are stationary at level at $5 \%$ and $10 \%$ level of significance respectively. The PP test on the other hand reveals that all variables have unit root at first difference except $\operatorname{lnPD}$ which is stationary at level at $10 \%$ level of significance. However, using KPSS test we found all variables are stationary at level.

Therefore after establishing that our variables are stationary at I(0) and I(1) the ARDL approach to co-integration as introduced by Pesaran et al (2001) and Bound test can be used. The ARDL model can be presented as follows;

$$
\begin{aligned}
& \Delta R G D P_{t}=\alpha_{0}+\sum_{i=1}^{\rho} \phi \Delta R G D P_{t-i}+\sum_{i=1}^{\rho} \phi \Delta \ln P D_{t-i}+\sum_{i=1}^{\rho} \lambda \Delta F D I_{-} I N F L_{t-i}+\sum_{i=1}^{\rho} \varphi \Delta \ln N O D A_{t-1}+\sum_{i=1}^{\rho} \delta \Delta E X R A T E_{t-1}+ \\
& \sum_{i=1}^{\rho} \delta \Delta \ln P R E D_{t-1}+\sigma_{1} R G D P_{t-1}+\sigma_{2} \ln P D_{t-1}+\sigma_{3} F D I_{-} I N F L_{t-1}+\sigma_{4} \ln N O D A_{t-1}+\sigma_{5} E_{X R A T E_{t-1}}+\sigma_{6} \ln P R E D_{t-1}+v_{t}
\end{aligned}
$$

The bounds technique is based on three validations. First, it necessitates the use of the ARDL model for the estimation of level relationships. Second, because the model suggests that once the order of the ARDL has been recognised, the relationship can be estimated by OLS. Third, it allows a mixture of $\mathrm{I}(1)$ and $\mathrm{I}(0)$ variables as regressors.

Table 2. ARDL model results

\begin{tabular}{cccc}
\hline Series & Coef. & t-statistics & Prob. \\
\hline RGDP(-1) & 0.110 & 0.751 & 0.4594 \\
RGDP(-2) & -0.492 & -3.106 & 0.0047 \\
LNPD & 0.342 & 1.473 & 0.1533 \\
FDI_INFL & -0.001 & -0.955 & 0.3488 \\
LNNODA & 2.123 & 1.458 & 0.1571 \\
LNNODA(-1) & 2.331 & 1.306 & 0.2032 \\
LNNODA(-2) & -2.508 & -1.775 & 0.0880 \\
EXRATE & 4.333 & 2.435 & 0.0224 \\
EXRATE(-1) & -2.862 & -1.704 & 0.1007 \\
LNPRED & -0.469 & -0.833 & 0.4123 \\
LNPRED(-1) & -0.257 & -0.314 & 0.7558 \\
LNPRED(-2) & -1.555 & -2.296 & 0.0303 \\
C & -6.723 & -0.516 & 0.6104 \\
R-squared & 0.77 & & \\
Adjusted R-squared & 0.67 & & \\
F-statistic & 7.161 & & \\
Prob(F-statistic) & 0.000 & & \\
Durbin -Watson stat & 2.536856 & & \\
\hline
\end{tabular}

*Note: p-values and any subsequent tests do not account for model selection.

The $\mathrm{R}$ square is $77.4 \%$ meaning that variation in dependent variable is explained by the explanatory variables and the rest of the variation is due to factors other than the independent variables. The validity of the model is represented by $\mathrm{F}$ - statistic, which is a measure of total explained variation divided by total unexplained variation. The higher the $\mathrm{F}$ - statistic, the better the overall fit of the regression line through the actual data.

Since the $\mathrm{p}$ - value is less than $5 \%$, we can conclude that all the independent variables have statistically significant explanatory power for the dependent variable (RGDP). The Durbin Watson (DW) statistic is a test for serial correlation of residuals of a time series regression. The statistic ranges from 0 to 4 with 0 indicating positive autocorrelation and 4 indicating negative autocorrelation. In our model DW is 2.5 which is a good indication of no autocorrelation in the sample. 
Table 3. Bound test output

\begin{tabular}{lcc}
\hline Test Statistic & Value & $\mathrm{k}$ \\
F-statistic & 6.638079 & 5 \\
\hline & & \\
Critical Value Bounds & & \\
\hline Significance & I0 Bound & I1 Bound \\
$10 \%$ & 2.08 & 3 \\
$5 \%$ & 2.39 & 3.38 \\
$2.5 \%$ & 2.7 & 3.73 \\
$1 \%$ & 3.06 & 4.15 \\
\hline
\end{tabular}

The F-statistics for the bound test is 6.63 this exceed the upper limit at $1 \%$ critical value of 4.15 . We strongly reject the null hypothesis of no long-run relationship. We can conclude that there is long run relationship among variables.

Table 4. Co-integration test output

\begin{tabular}{cccc}
\hline Series & Coef. & t-statistics & Prob. \\
\hline D(RGDP(-1)) & 0.508627 & 3.486119 & 0.0018 \\
D(LNPD) & 0.204844 & 1.128679 & 0.2697 \\
D(FDI_INFL) & -0.001092 & -0.941925 & 0.3552 \\
D(LNNODA) & 2.135632 & 1.933132 & 0.0646 \\
D(LNNODA(-1)) & 2.601788 & 2.450786 & 0.0216 \\
D(LNEXRATE) & 4.358960 & 3.931580 & 0.0006 \\
D(LNPRED) & -0.355854 & -0.672812 & 0.5072 \\
D(LNPRED(-1)) & 1.775918 & 3.232719 & 0.0034 \\
CointEq(-1) & -1.418664 & -7.457991 & 0.0000 \\
\hline Cointeq $=$ RGDP $-(0.2473 *$ LNPD - $0.0008 *$ FDI_INFL +1.4056*LNNODA & $+1.0637 *$ EXRATE \\
$-1.6500 *$ LNPRED -4.8606$)$ & & \\
\hline
\end{tabular}

The error correction term or coefficient is negative $(-1.41)$ as required and it is statistically significant at 0.0000 p-value.

Table 5. Long run coefficients results

\begin{tabular}{cccc}
\hline Series & Coef. & t-statistics & Prob. \\
\hline LNPD & 0.247338 & 1.487839 & 0.1493 \\
FDI_INFL & -0.000806 & -0.966916 & 0.3428 \\
LNNODA & 1.405630 & 2.149674 & 0.0414 \\
EXRATE & 1.063662 & 6.278354 & 0.0000 \\
EXRATE(-1) & -1.650028 & -3.566886 & 0.0015 \\
LNPRED & -4.860593 & -0.514247 & 0.6116 \\
C & 0.247338 & 1.487839 & 0.1493 \\
\hline
\end{tabular}

$R G D P=-4.8606+0.24 \ln P D-0.0008 F D I_{-} I N F L+1.40 \ln N O D A+1.06 E X R A T E-1.65 \ln P R E D$

From the above regression model our variables RGDP, LNPD, FDI-INFL, LNNODA, LNPRED, and EXRATE indicate long-run equilibrium relationship. There is relatively quick adjustment in the RGDP when the dependent variables change. The coefficients indicate that a $10 \%$ increase in external debt (PD) results in the long run increase by $24 \%$ of economic growth (RGDP) but this change is statistically insignificant at 0.14 P-value which is greater than 5\%. Again, FDI inflow coefficient is negative and is also not significant indicating that an increase in FDI Inflow has a negative impact on economic growth (RGDP) by (-0.0008) considering other variables constant. Both 
NODA and EXRATE have positive and significant impact on economic growth. However, PRED shows a negative relationship with economic growth but is statistically significant at $0.0015 \mathrm{p}$ - value which is less than 5 percent.

We can therefore say that, external debts contribute to economic growth in Tanzania. However, it is advised that external debt be well managed and invested in viable projects for which reasonable returns can be generated to be used for debt servicing and stimulate investment. In case of FDI inflow, our analysis indicates a negative and insignificant impact on economic growth in Tanzania. Although different tests to check the goodness of our model show the model is good, the results are inconsistent with our prediction.

\section{Summary and Conclusion}

The objectives of this study were to explore the impact of public debt and FDI on economic growth in Tanzania. We used time series data which were collected from secondary sources for the period from 1971 - 2011 with the view to achieve the stated objectives. The results indicate that, in the long-run external debt has a positive impact on economic growth. This implies that an increase in external debt will propel economic growth. On the other hand, FDI has a negative impact on economic growth meaning that an increase in FDI will result in a decrease in economic growth. Therefore external debts in Tanzania are required to stimulate economic growth. To achieve this, proper management of external debts is required as debt servicing is a serious impediment to economic growth and development. However, there is a need to look at how FDI could positively contribute to economic growth in Tanzania. The absorptive capacity and proper policies are necessary for the host country to realize the potentials from FDI, for example diffusion of advanced technology, increase employment, tax revenue and spillover effect to stimulate the economy. There is a need for Policy makers to emphasize on a win - win situation in contracts signing. The foreign investors have to work in joint ventures by local investors for easy transfer of technology. However, domestic investment would be emphasized to promote economic growth in Tanzania.

\section{References}

Alfaro, L. et al. (2004). FDI and Economic Growth: The role of financial Markets. Journal of International Economics, 64(1), 89-112. http://dx.doi.org/10.1016/S0022-1996(03)00081-3

Al-Khathlan, K. (2013). Foreign direct investment inflows and economic growth in Saudi Arabia: a co - integration analysis. Review of Economics \& Finance, 4, 70-80.

Ayanwale, A. B. (2007). FDI and economic Growth: Evidence from Nigeria. AERC research paper 165, Nairobi: AERC.

Baldacci, E., \& Kumar, M. S. (2010). Fiscal Deficits, Public Debt and Sovereign Bond Yields. IMF WP/10/184.

Bank of Tanzania, 2015.

Benedict, C. et.al. (2003). External Debt, Public Investment, and Growth in Low- Income Countries. International Monetary Fund. WP/03/249.

Chauvin, N. D., \& Kraay A. (2005). What had 100billion dollars worth of debt relief done for low income Countries? World Bank, Washington DC, USA.

Dickey, D. A., \& Fuller, W. A. (1979). Distribution of the estimators for autoregressive time series with a unit root. Journal of the American Statistical Association, 74, 427-431.

Gale, W. G., \& Orszarg, P. (2003). The Economic Effects of Long-term Fiscal Discipline. Urban- Brookings Tax Policy Centre Discussion paper No. 8. Washington: Brooking Institution.

Granger, C. J. W., \& Swanson, N. R. (1996). An Introduction to Stochastic Unit Root Processes.

Hendry, D. F., \& Juselius, K. (2000). Explaining cointegration analysis: Part I. Energy Journal, 21, 1-42. http://dx.doi.org/10.5547/ISSN0195-6574-EJ-Vol21-No1-1

Islam, K. M. A. (2014). Foreign Direct Investmentn(FDI) in Bangladesh: Prospects Challenges and Its Impact on Economy. Asian Business Review, 4(1), 24-36.

Iyoha, M. A. (1997). Policy Simulations with Model of External Debt and Economic Growth in Sub-Sahara African Countries. Nigeria Economic and Financial Review, 2.

Melnyk, L., Kubatko, O., \& Pysarenko, S. (2014). The impact of foreign direct investment on economic growth: case of post communism transition economies. Problems and perspectives in Management, 12(1), 17-24.

Michael, O., \& La, S. (2012). External Debt, Economic Growth and Investment in Nigeria. European Journal of Business Management, 4(2), 67-75. 
Ndulu, B. J. (1994). Tanzania's Economic Development: Lessons from the Experience and Challenges for the Future, published in Development Challenges and strategies for Tanzania - An agenda for the $21^{\text {st }}$ Century, Economic Research Bureau/Department of Economics, Dar es Salaam University press, Dar es Salaam.

Perkins, D. H. (2001). Industrial and financial policy in China and Vietnam. In J.E and S. Yusuf (Eds.), Rethinking the Asian Miracle. New York, Oxford University Press.

Pesaran, M. H., Shin, Y., \& Smith, R. (2001) Bounds testing approaches to the analysis of level relationships. Journal of Applied Econometrics, 16, 289-326. http://dx.doi.org/10.1002/jae.616

Saqib, N. et al. (2013). Impact of Foreign Direct Investment on Economic Growth of Pakistan. Advances in Management \& Applied Economics, 3(3), 35-45.

SidratulMuntah et al. (2015). Impact of Foreign Direct Investment on Economic Growth of Pakistan. American Research Journal of Business and Management, 1, 7-11.

Tanzania Investment Report, 2012.

UNCTAD Report, 2014.

Wamboye, E. (2012). External Debt, Trade and FDI on Economic Growth of Least Developed Countries. Cambridge Business \& Economics Conference, Cambridge, UK. 